\title{
IDENTIFICATION OF NATURAL ANTIFUNGAL CONSTITUENTS FROM AGARICUS BISPORUS (J. E. LANGE) IMBACH
}

\author{
WAQAS, H. M. ${ }^{1}$ - AKBAR, M..$^{1 *}$ KHALIL, T. ${ }^{1}$ - ISHFAQ, M. ${ }^{2}$ - ASLAM, N. ${ }^{1}-$ CHOHAN, S. A. ${ }^{1}-$ \\ SIDDIQI, E. H. ${ }^{1}-$ IQBAL, M. S. ${ }^{1}$ \\ ${ }^{1}$ Department of Botany, University of Gujrat, Gujrat, 50700 Pakistan \\ (e-mails:vk6296717@gmail.com, tayyaba.khalil@uog.edu.pk,nazirmbdin@gmail.com, \\ meriuog@gmail.com,ejaz.hussain@uog.edu.pk,drsajjad.iqbal@uog.edu.pk) \\ ${ }^{2}$ Institute of Molecular Biology and Biotechnology, The University of Lahore, Defence Road \\ Campus, Lahore, Pakistan \\ (e-mail: ishfaq80@hotmail.com) \\ *Corresponding author \\ e-mail: makbarpu@gmail.com; phone: +92-333-764-5058
}

(Received 14 ${ }^{\text {th }}$ Aug 2018; accepted $1^{\text {st }}$ Nov 2018)

\begin{abstract}
In agriculture, fungal invasions cause heavy loss and affect food security and food safety. Chemical pesticides are available to control these pathogens but these are associated with environmental and public health concerns. In recent years, there is a growing trend towards nature friendly methods of pathogen control. Use of allelochemicals from mushrooms is a promising field. In the present study, antifungal activity of an edible mushroom, Agaricus bisporus was investigated. For this purpose, different organic solvent extracts of A. bisporus, were evaluated against plant pathogenic fungal species viz. Macrophomina phaseolina, Aspergillus flavus, Fusarium oxysporum, Drechslera australiensis and Alternaria alternata. To check the antifungal activity of A. bisporus, serial dilution method was used. Six levels of treatments of each $n$-hexane, chloroform and ethyl acetate $(0,5,10,15,20$ and $25 \mathrm{mg} / \mathrm{ml})$ were applied against all fungal species. Generally, all organic solvent extracts reduced the fungal biomass significantly with the increase in concentration but, ethyl acetate fraction exhibited better results and reduced the fungal growth in some species up to $50 \%$ in D. australiensis and $44 \%$ each in A. alternata and $F$. oxysporum. From Gas Chromatography Mass Spectrometry (GCMS) analysis of ethyl acetate fraction, 10 compounds were identified. Out of these 10 compounds, only one compound [1,2Benzenedicarboxylic acid, mono (2-ethylhexyl) ester], molecular formula $=\mathrm{C}_{16} \mathrm{H}_{22} \mathrm{O}_{4}$ and molecular weight $=278$, showed $91.31 \%$ peak value. It was concluded that this compound being in the highest concentration in the ethyl acetate fraction of A. bisporus mushroom was responsible for its antifungal activity, recorded in the present study. The present investigation concluded that $A$. bisporus has bioactive compounds that can be exploited to develop ecofriendly fungicides against a number of plant pathogens.
\end{abstract}

Keywords: button mushroom, bioactive compounds, allelochemicals, GCMS

\section{Introduction}

Bioactive compounds from mushrooms have been the most important source of biologically active compounds (Mishra and Tiwari, 2011; Kothari, et al., 2018). Mushrooms are recognized as important source of pharmacologically active compounds (Dimitrijević et al., 2017). These biologically active compounds are used in different forms like oils (Mehrparvar et al., 2016) and remedies and many of these biologically natural active compounds are still unidentified (Matijaševic et al., 2016). Moreover, in agriculture, fungal invasions bring about serious reduction in the quality and yield of crops and incur enormous economic losses. At present the most reliable method to control these fungal pathogens is the use of chemical/synthetic fungicides. But the repeated use of these synthetic compounds causes number of ill effects, e.g. health 
hazards, environmental pollution and antifungal resistance (Revie et al., 2018). So, there is dire need to seek nature friendly alternatives to these synthetic chemicals and mushrooms are good source of these alternatives (Gargano et al., 2017).

In several cases, mushroom bioactive compounds show very high activity than the synthetic antifungals frequently used now-a-days (Heleno et al., 2013; Thatoi et al., 2018). Similarly, Pleurotus ostreatus and Lentinula edodes extracts exhibit antifungal activity against plant pathogenic fungal species viz. Fusarium oxysporum.

Agaricus bisporus (Button mushroom) is a Basidiomycete fungus, native to Europe and America. This mushroom is the most cultivated mushroom of the world (Maa et al., 2018). At present it accounts for 35-45\% of throughout world production of edible mushrooms (Masoumi et al., 2015). Moreover, studies show that this mushroom has antifungal properties (Hamid and Rezaeian, 2016). In an investigation, methanolic extract of $A$. bisporus showed $21 \mathrm{~mm}$ zone of inhibition against $F$. oxysporum (Waithaka et al., 2017). Öztürk et al. (2011) reported that methanolic extract of three Agaricus species viz. Agaricus essettei, Agaricus bitorquis and A. bisporus, exhibited $76.50 \%, 77.44 \%$, and $78.72 \%$ antifungal activity against Penicillium verucosum. As there are numerous investigations regarding isolation of bioactive compounds having antifungal activity of $A$. bisporus as well as other mushrooms throughout world but such reports are missing on Pakistani mushroom species. Moreover, past investigations regarding antifungal activity of $A$. bisporus were mostly conducted on human/animal related pathogens and very few on plant pathogens. So, in the present investigation, antifungal activity was determined on some notorious plant pathogenic fungi viz. Macrophomina phaseolina, Aspergillus flavus, Fusarium oxysporum, Drechslera australiensis and Alternaria alternata. These fungi cause a number of serious plant diseases, e.g., some of the fungal diseases which largely affect crops are, A. alternata that causes Alternaria black spot of rose, Colletotrichum gloeosporioides infects loquat and Fusarium solani causes strawberry fruit rot (Abbas, et al., 2017; Naz, et al., 2017; Mehmood et al., 2017). A. flavus produces maize ear rots and mycotoxin contamination (Shu et al., 2015). Acacia nilotica is affected by D. australiensis (Ahmad et al., 2017). Fusarium head blight of wheat caused by Fusarium graminearum (Li et al., 2015), M. phaseolina is a phytopathogen causing stalk rot in soybean crop (Ramos et al., 2016). M. phaseolina has been reported to infect about 500 plant species and no commercial fungicide has been recommended so far to combat this fungal pathogen (Javaid et al., 2017). These fungal pathogens have been difficult to control by synthetic fungicides. So, the present study was undertaken to evaluate in vitro antifungal activity of constituents of $A$. bisporus partitioned through organic solvents like $n$-hexane, chloroform and ethyl acetate. This study would help to identify natural eco-friendly antifungal compounds in A. bisporus.

\section{Materials and methods}

Experiments were performed in Medicinal Flora Evaluation, Characterization and Metabolomics Lab., Department of Botany, University of Gujrat, Gujrat, Pakistan during the year 2017.

\section{Culturing of fungal isolates and storage}

Isolates of fungal species with accession number viz. Macrophomina phaseolina (FCBP-PTF-1156), Aspergillus flavus (FCBP-SF-1261), Fusarium oxysporum, (FCBP- 
SF-1175), Drechslera australiensis (FCBP-AF-482) and Alternaria alternata (FCBPPTF-1285) were purchased from culture bank of University of the Punjab, Lahore, Pakistan. These fungal cultures were subcultured on Potato Dextrose Agar (PDA) medium for mass culturing and stored in a refrigerator (Haier) at $4{ }^{\circ} \mathrm{C}$ for further use.

\section{Preparations of mushroom extracts}

Agaricus bisporus mushroom, (white, cultivated), was purchased from Margalla Mushroom Industries, Islamabad, Pakistan. The mushroom was sun dried for 7 days. The dried mushroom was ground to powder in pestle and mortar. This dried mushroom powder $(220 \mathrm{~g})$ was first soaked into $1.5 \mathrm{~L}$ methanol (Company; BDH) in a glass jar for 7 days and after that the mixture was filtered by using Whatman no. 1 and evaporated by using rotary evaporator (Heidolph Laborata 4000 efficient) at $45^{\circ} \mathrm{C}$. This methanolic extract was reconstituted with distilled water $\left(\mathrm{dH}_{2} \mathrm{O}\right)$ and then partitioned with different organic solvents viz. $n$-hexane, chloroform and ethyl acetate, in order of their increasing polarity in separating funnels to obtain the $n$-hexane, chloroform and ethyl acetate extracts. Organic solvents were evaporated under vacuum in rotary evaporator as above to obtain organic solvent extracts. Resulting extracts were stored at $4{ }^{\circ} \mathrm{C}$ for further use (Akbar et al., 2017).

\section{Antifungal assays}

Stock solutions of all partitioned extracts viz. $n$-hexane, chloroform and ethyl acetate were synthesized following procedure as described by Ali et al. (2017) and Azhar et al. (2018), with slight modifications like use of lower concentrations of extracts. $150 \mathrm{mg}$ of mushroom extract in each organic solvent extracted was dissolved into $166 \mu \mathrm{l}$ of Dimethyl sulfoxide (DMSO) and final volume was raised to $500 \mu 1$ with the addition of distilled autoclaved water. Control mixture comprised of $166 \mu \mathrm{DMSO}$ and its final volume raised to $500 \mu \mathrm{l}$ by the addition of distilled autoclaved water $(333 \mu \mathrm{l})$. Potato Dextrose Broth (PDB) was prepared by following standard procedures. Overall six concentrations were investigated as follow; $0,5,10,15,20$ and $25 \mathrm{mg} / \mathrm{ml}$ of each extract separately. The experiment was done in glass vials for $72 \mathrm{~h}$ at $27^{\circ} \mathrm{C}$. The experiment was performed using Completely Randomised Design (CRD) with three replications. At harvest fungal biomass was measured with the help of digital balance (AY120, Shimadzu Corporation, Japan). Fungal biomass was filtered on preweighed filter papers, dried in an electric oven (UNE-600, Memmert, Germany) at $70{ }^{\circ} \mathrm{C}$ till constant weight. After drying, these filter papers were again weighed to calculate fungal biomass.

\section{Gas chromatography mass spectrometry (GCMS) analysis}

The biochemical constituents of ethyl acetate extract of $A$. viridis were analysed by using GCMS with model number 7890A/5975C of Agilant Technologies in the Department of Chemistry, Forman Christian College University, Lahore, Pakistan. GCMS instrument was equipped with column \# HP-5MS $(30 \mathrm{~m} \times 250 \mu \mathrm{m} \times 0.25 \mu \mathrm{m})$. Helium gas with $99.99 \%$ purity was used with constant flow rate at $1 \mathrm{~mL} \mathrm{~min}{ }^{-1}$. Material was employed with injection of $2 \mu \mathrm{L}$ volume. In injector the temperature was $240{ }^{\circ} \mathrm{C}$. Oven temperature was programmed first from $60{ }^{\circ} \mathrm{C}$ for $2 \mathrm{~min}$ with increase of $5{ }^{\circ} \mathrm{C} \mathrm{min}{ }^{-1}$ to $80{ }^{\circ} \mathrm{C}$, then $10{ }^{\circ} \mathrm{C} \min ^{-1}$ to $310{ }^{\circ} \mathrm{C}$ for $5 \mathrm{~min}$. Total $\mathrm{GC}$ running time was 34 min. Relative quantities of all constituents were computed by using same method as described by Jananie et al. (2012). 


\section{Statistical analysis}

For statistical analysis, ANOVA was performed followed by Duncan's Multiple Range Test (DMRT) to analyze the treatment means by using computer software, CosStat.

\section{Results and discussion}

\section{Antifungal activity of $n$-hexane, chloroform and ethyl acetate extract against Macrophomina phaseolina}

Data regarding the effect of $n$-hexane extract of $A$. bisporus on the growth of $M$. phaseolina are shown in Figure 1A. $n$-hexane extract of A. bisporus concentrations ranging from 5, 10, 15, 20 and $25 \mathrm{mg} / \mathrm{ml}$ showed slight significant reduction in fungal biomass.

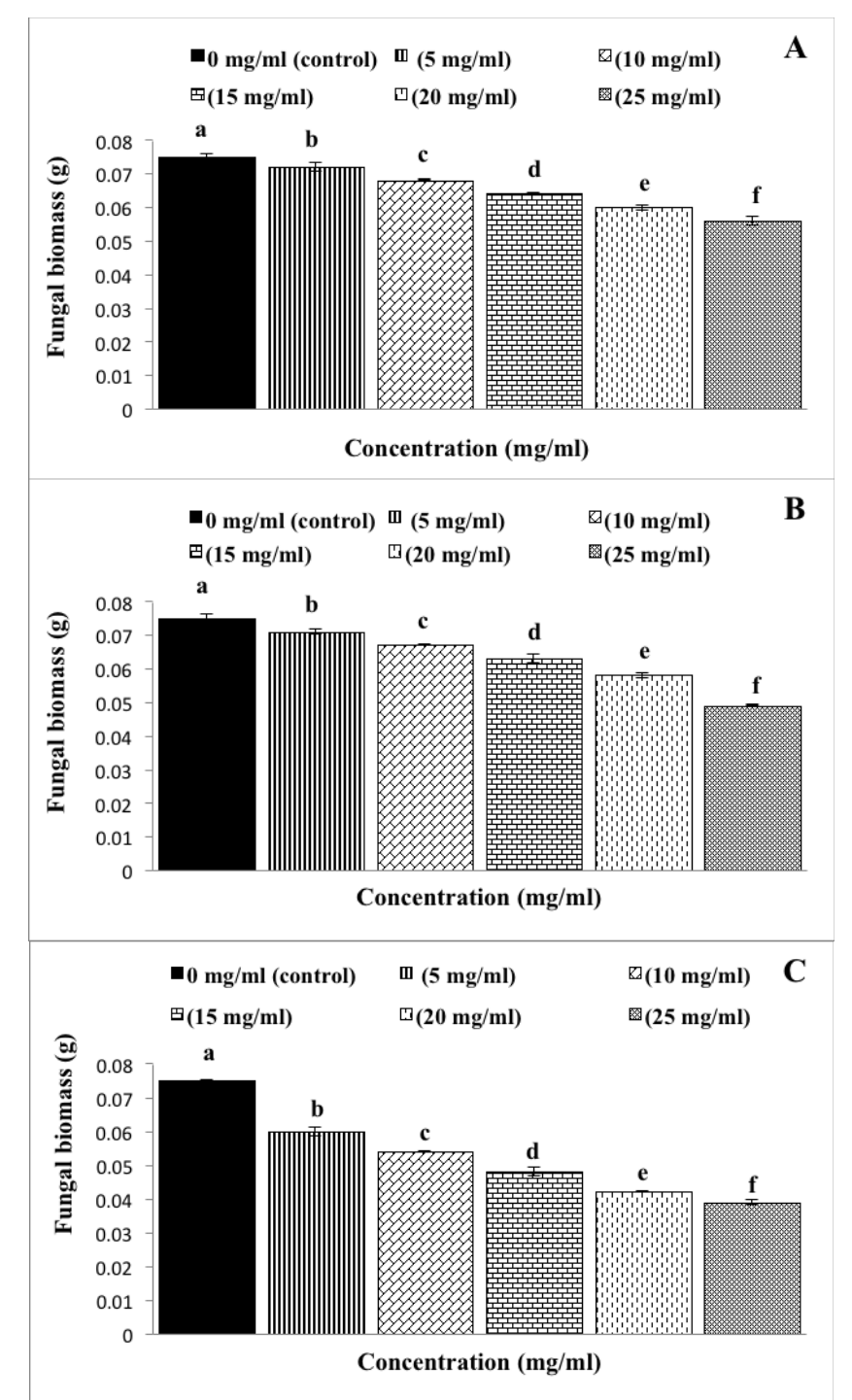

Figure 1. Effect of different concentrations of $(A) n$-hexane, (B) Chloroform and $(C)$ ethyl acetate extract of Agaricus bisporus on biomass of Macrophomina phaseolina. Values topped with distinctive letters show a significant variance $(P \leq 0.05)$, as analyzed by DMRT 
These extract concentrations caused 6, 9, 14, 20 and 25\% reduction in fungal biomass as compared to control (DMSO). Different $n$-hexane extract concentrations ranging from 5 to $25 \mathrm{mg} / \mathrm{ml}$ of $A$. bisporus showed slight reduction in fungal biomass from 4 to $25 \%$ as compared to control (DMSO). The effect of chloroform extract of A. bisporus, on the biomass of plant pathogenic fungi, $M$. phaseolina with same concentrations is shown in Figure $1 B$. According to data, gradual decrease in fungal biomass from 5, 10, 16, 22 and $34 \%$ was observed with an increase of extract concentration. The effect of chloroform extract of mushroom A. bisporus on the biomass of plant pathogenic fungi, $M$. phaseolina with same concentrations was higher as compared to $n$-hexane extract and there was a gradual decrease in fungal biomass from 5 to 34\%. Data about the antifungal activity of ethyl acetate extract of A. bisporus on $M$. phaseolina showed pronounced reduction in fungal biomass. In this case, a decline of 10, 19, 28, 37 and $41 \%$ was noted as compared to control. Antifungal activity of ethyl acetate extract of $A$. bisporus on $M$. phaseolina showed clear-cut reduction in biomass from 10 to $41 \%$ as compared to control. Maximum $41 \%$ decrease in biomass was noted against $25 \mathrm{mg} / \mathrm{ml}$ concentration. It was seen that ethyl acetate extract showed better response at all levels against the growth of $M$. phaseolina (Table 1 and Fig. 1C). Previously no results were reported against this fungus in literature.

Table 1. ANOVA of the data for the effect of $n$-hexane, chloroform and ethyl acetate extract of Agaricus bisporus on biomass of Macrophomina phaseolina

\begin{tabular}{c|c|c|c|c|c|c|c}
\hline \multirow{2}{*}{ Source } & \multirow{2}{*}{ df } & \multicolumn{2}{|c|}{ n-hexane } & \multicolumn{2}{c|}{ Chloroform } & \multicolumn{2}{c}{ Ethyl acetate } \\
\cline { 3 - 8 } & & F & P & F & P & F & P \\
\hline $\begin{array}{c}\text { Main effects } \\
\begin{array}{c}\text { Fusarium oxysporum } \\
\text { Error }\end{array}\end{array}$ & 5 & 181.71 & $.00 * * *$ & 801.77 & $.00 * * *$ & 495.63 & $.00 * * *$ \\
\hline Total & 12 & & & & & & \\
\hline
\end{tabular}

\section{Antifungal activity of n-hexane, chloroform and ethyl acetate extract against Aspergillus flavus}

Data in Figure $2 A$ show that different concentrations of $n$-hexane extract did not show potent antifungal effects on A. flavus. Different concentrations of this extract exhibited different levels of inhibition in terms of reduction in fungal biomass. Maximum $18 \%$ inhibition was measured at $25 \mathrm{mg} / \mathrm{ml}$ concentration as compared to control. While, in other concentrations, the fungal biomass reduced in a very low quantity. Whereas, data about the results of chloroform extract of $A$. bisporus against plant pathogenic fungus, A. flavus are shown in Figure $2 B$. The fungal biomass was decreased from 3 to $21 \%$ in comparison with control. Very low decrease was seen at $5 \mathrm{mg} / \mathrm{ml}$ concentration but this activity further increases with the uplift level of extract concentration. Effect of ethyl acetate extract on A. flavus showed significant results as shown in Figure $2 C$. In this case different concentrations of ethyl acetate extract caused $13,18,23,32$ and $42 \%$ decline in fungal biomass at 5, 10, 15, 20 and $25 \mathrm{mg} / \mathrm{ml}$ ethyl acetate extract concentration (Table 2). These results are in the agreement with findings of previous workers (Dutta et al., 2013; Kumar and Yadav, 2014) that reported 77.12\% antifungal activity against $A$. flavus when extract of $A$. bisporus was investigated in diffusion disk method. 


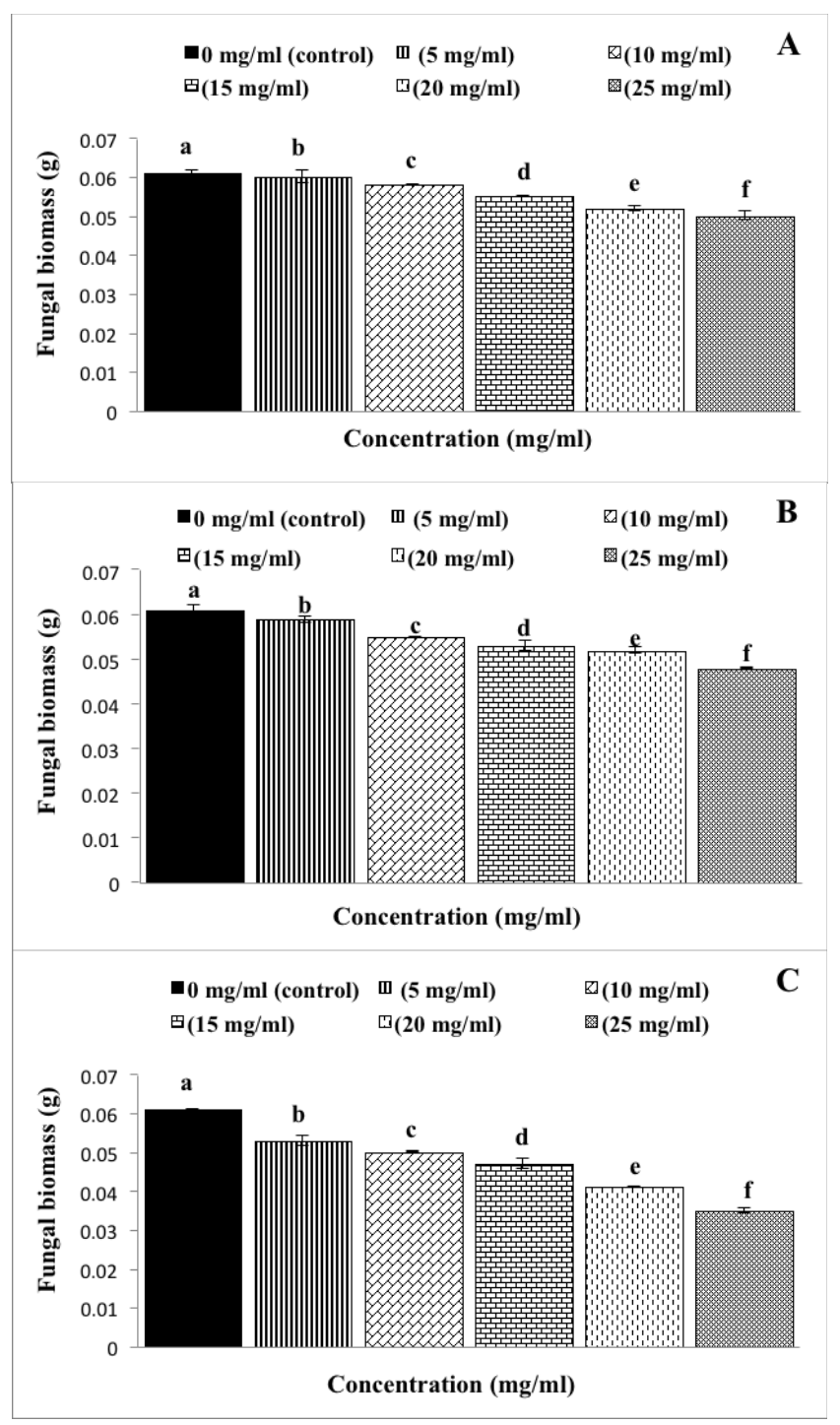

Figure 2. Effect of different concentrations of $(A) n$-hexane, (B) Chloroform and $(C)$ ethyl acetate extract of Agaricus bisporus on biomass of Aspergillus flavus. Values topped with distinctive letters show a significant variance $(P \leq 0.05)$, as analyzed by DMRT

Table 2. ANOVA of the data for the effect of n-hexane, chloroform and ethyl acetate extract of Agaricus bisporus on biomass of Aspergillus flavus

\begin{tabular}{c|c|c|c|c|c|c|c}
\hline \multirow{2}{*}{ Source } & \multirow{2}{*}{$\mathbf{d f}$} & \multicolumn{2}{|c|}{$\boldsymbol{n}$-hexane } & \multicolumn{2}{c|}{ Chloroform } & \multicolumn{2}{c}{ Ethyl acetate } \\
\cline { 3 - 7 } & & $\mathbf{F}$ & $\mathbf{P}$ & $\mathbf{F}$ & $\mathbf{P}$ & $\mathbf{F}$ & $\mathbf{P}$ \\
\hline $\begin{array}{c}\text { Main effects } \\
\text { Fusarium oxysporum } \\
\text { Error }\end{array}$ & 5 & 100.02 & $.00 * * *$ & 166.62 & $.00 * * *$ & 800.7 & $.00 * * *$ \\
\hline Total & 12 & & & & & & \\
\hline
\end{tabular}

In past investigation, methanolic extract of mushroom, Meripilus giganteus also exhibited antifungal activity against some plant pathogenic fungal species viz. Aspergillus versicolor, Aspergillus niger, Aspergillus ochraceus, Penicillium 
funiculosum, Aspergillus fumigatus, Trichoderma viride and Penicillium ochrochloron, keeping bifonazole and Ketoconazole as control. The extract showed only $10 \%$ inhibition in case of $A$. ochraceus as compared to bifonazole while, only $1 \%$ minimum inhibitory concentration (MIC) as compared to ketoconazole. Mushroom M. giganteus showed very poor antifungal activity against all other fungal pathogens (Stojkovi et al., 2017).

\section{Antifungal activity of $n$-hexane, chloroform and ethyl acetate extract against Fusarium oxysporum}

$n$-hexane extract of test mushroom did not reduce the fungal biomass to great extent. $n$-hexane extract of $A$. bisporus showed only 3,5,9,13 and $17 \%$ reduction in fungal biomass in contrast to control (Fig. 3A). The chloroform extract of A. bisporus depicted significant reduction on biomass $F$. oxysporum. Different concentrations of test extract incurred 3, 7, 11, 18 and $24 \%$ decline in fungal biomass as compared to control (Fig. 3B).

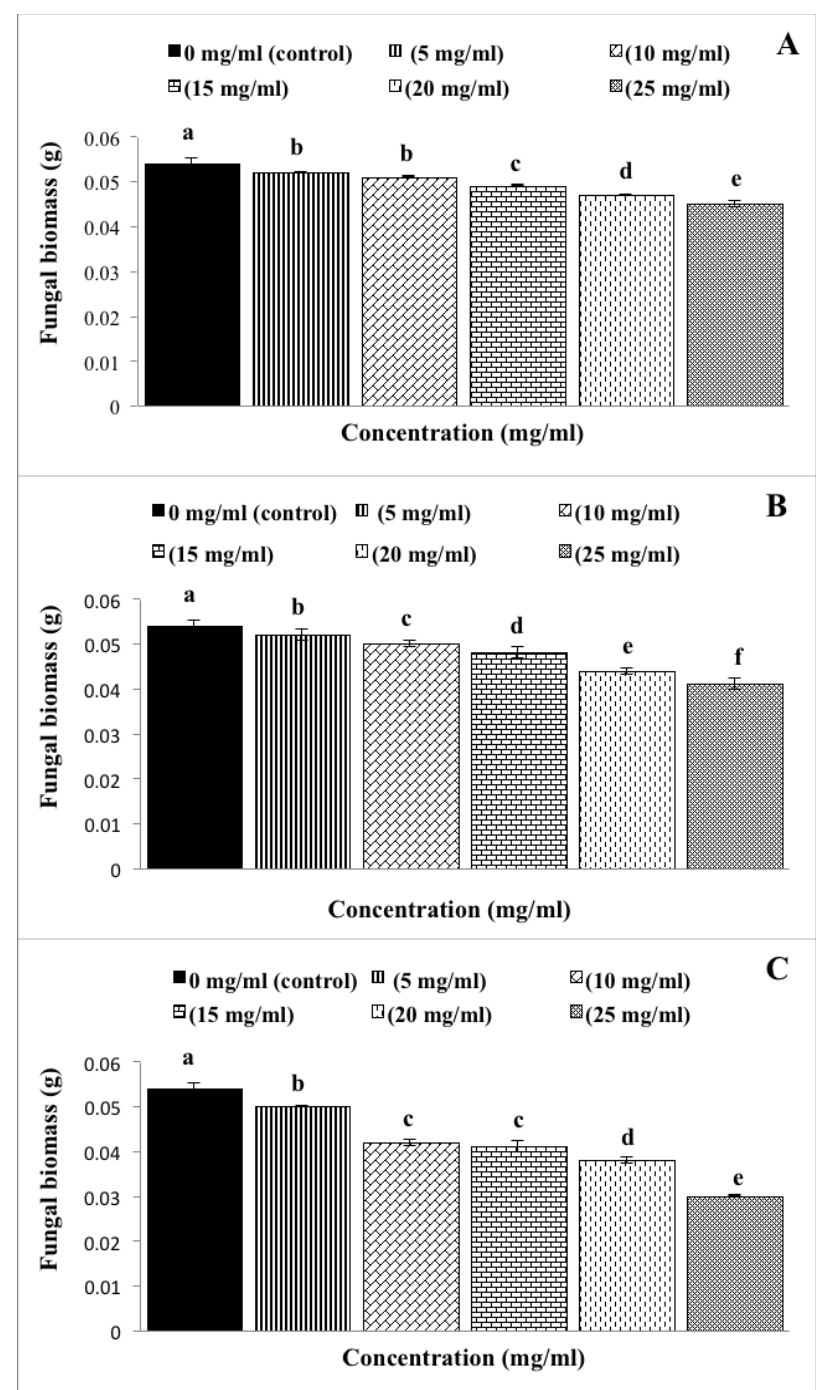

Figure 3. Effect of different concentrations of (A) $n$-hexane, (B) Chloroform and $(C)$ ethyl acetate extract of Agaricus bisporus on biomass of Fusarium oxysporum. Values topped with distinctive letters show a significant variance $(P \leq 0.05)$, as analyzed by DMRT 
On the other hand ethyl acetate extract of A. bisporus revealed relatively higher significant reduction in fungal biomass as compared to control. Different employed concentrations caused 7,22, 24, 29 and $44 \%$ decrease in test fungal biomass when compared with control (Table 3 and Fig. 3C). In this experiment, ethyl acetate showed $44 \%$, chloroform $24 \%$ and $n$-hexane $17 \%$ reduction in biomass at $25 \mathrm{mg} / \mathrm{ml}$ concentration and similar results were reported by Jin and Huang (2011) and Waithaka et al. (2017) in A. bisporus that showed $37 \%$ antifungal activity against $F$. oxysporum. This enhanced activity of extracts used in the present study might be due the presence of different chemical constituents in the mushroom sample used herein. As the environment plays a major role in the abundance of different metabolites in a particular species, it may be envisaged that the pronounced bioactivity observed in A. bisporus grown in Pakistan may have different metabolite profile.

Table 3. ANOVA of the data for the effect of $n$-hexane, chloroform and ethyl acetate extract of Agaricus bisporus on biomass of Fusarium oxysporum

\begin{tabular}{c|c|c|c|c|c|c|c}
\hline \multirow{2}{*}{ Source } & \multirow{2}{*}{ df } & \multicolumn{2}{|c|}{$\boldsymbol{n}$-hexane } & \multicolumn{2}{c|}{ Chloroform } & \multicolumn{2}{c}{ Ethyl acetate } \\
\cline { 3 - 7 } & & $\mathbf{F}$ & $\mathbf{P}$ & $\mathbf{F}$ & $\mathbf{P}$ & $\mathbf{F}$ & $\mathbf{P}$ \\
\hline $\begin{array}{c}\text { Main effects } \\
\text { Fusarium oxysporum }\end{array}$ & 5 & 67.09 & $.00 * * *$ & 152.4 & $.00 * * *$ & 143.61 & $.00 * * *$ \\
Error & 12 & & & & & & \\
\hline Total & 17 & & & & & & \\
\hline
\end{tabular}

\section{Antifungal activity of n-hexane, chloroform and ethyl acetate extract against Drechslera australiensis}

$n$-hexane extract of $A$. bisporus caused a decline of $2,6,13,19$ and $25 \%$ at different concentrations viz. 5, 10, 15,20 and $25 \mathrm{mg} / \mathrm{ml} n$-hexane extract concentrations, respectively (Fig. 4A). Whereas, extract in chloroform showed 4, 8, 13, 21 and 29\% biomass reduction against fungus, $D$. australiensis at these corresponding extract concentrations (Fig. 4B). On the other hand, better antifungal activity was recorded in case of ethyl acetate extract at diverse concentrations ranging from 5 to $25 \mathrm{mg} / \mathrm{ml}$. There was significant reduction of $6,12,21,33$ and $50 \%$ at $5,10,15,20$ and $25 \mathrm{mg} / \mathrm{ml}$ ethyl acetate extract concentrations, respectively (Fig. 4C). Though all treatments in $n$ hexane, chloroform and ethyl acetate showed antifungal effect but ethyl acetate showed better potency as compared to other two extracts at all levels of treatments. Before this, in literature no bioactivity was reported against $D$. australiensis in terms of fungal metabolites (Table 4 and Fig. 4A, B, C).

Table 4. ANOVA of the data for the effect of n-hexane, chloroform and ethyl acetate extract of Agaricus bisporus on biomass of Drechslera australiensis

\begin{tabular}{c|c|c|c|c|c|c|c}
\hline \multirow{2}{*}{ Source } & df & \multicolumn{2}{|c|}{ n-hexane } & \multicolumn{2}{c|}{ Chloroform } & \multicolumn{2}{c}{ Ethyl acetate } \\
\cline { 3 - 8 } & & F & P & F & P & F & P \\
\hline $\begin{array}{c}\text { Main effects } \\
\begin{array}{c}\text { Fusarium oxysporum } \\
\text { Error }\end{array}\end{array}$ & 5 & 46.64 & $.00 * * *$ & 67.58 & $.00 * * *$ & 157.98 & $.00 * * *$ \\
\hline Total & 12 & & & & & & \\
\hline
\end{tabular}




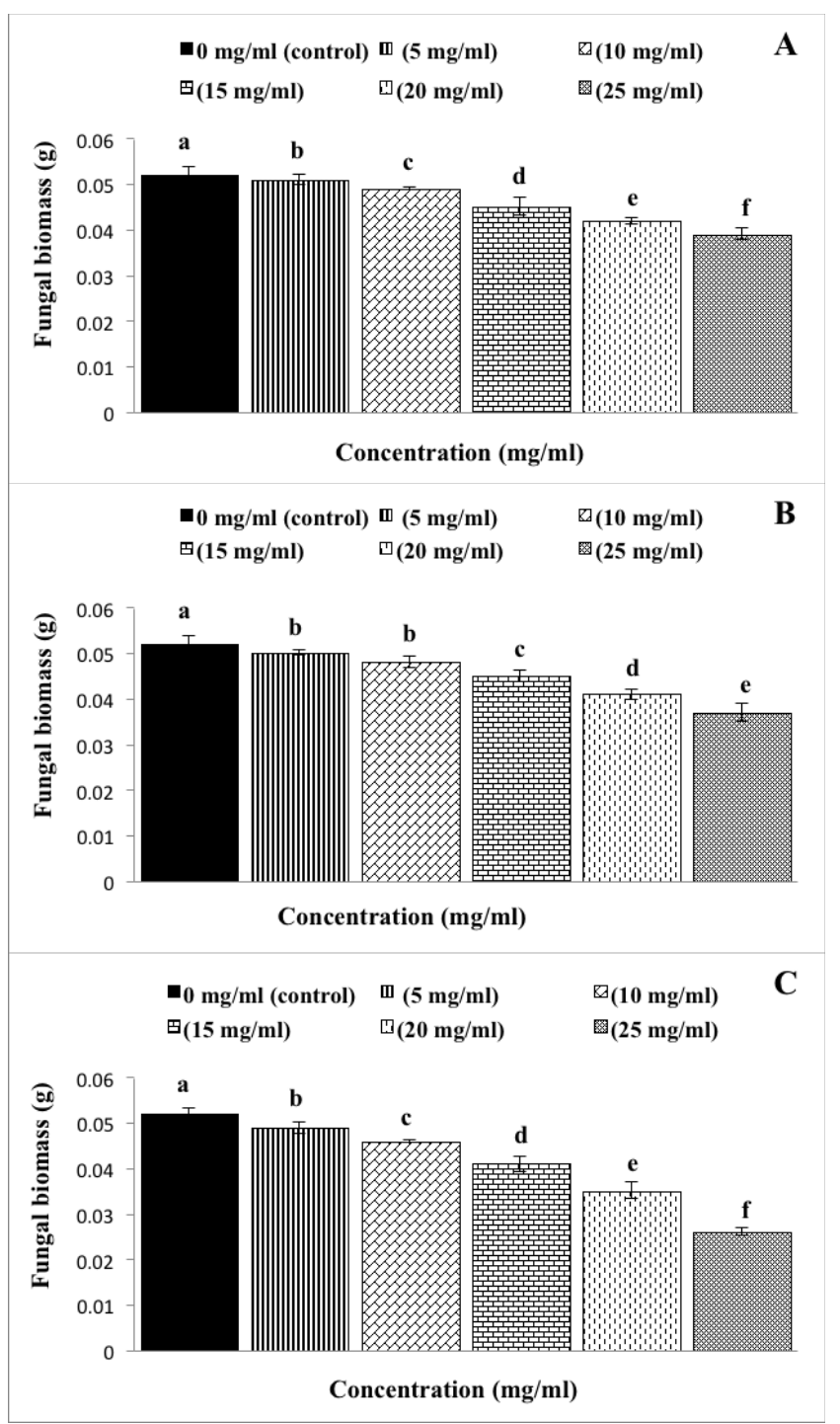

Figure 4. Effect of different concentrations of (A) n-hexane, (B) Chloroform and $(C)$ ethyl acetate extract of Agaricus bisporus on biomass of Drechslera australiensis. Values topped with distinctive letters show a significant variance $(P \leq 0.05)$, as analyzed by DMRT

\section{Antifungal activity of $n$-hexane, chloroform and ethyl acetate extract against Alternaria alternata}

$n$-hexane extract of test mushroom did not show significant results in response to fungal biomass at all concentrations of test extract as shown in Figure 5A. There was non-significant reduction in fungal biomass at 5 and $10 \mathrm{mg} / \mathrm{ml}$ extract concentration. While at higher concentrations of 15,20 and $25 \mathrm{mg} / \mathrm{ml}$, there was 9,14 and $20 \%$ significant reduction in biomass of A. alternata as compared to control (Fig. 5A). In case of chloroform extract of $A$. bisporus at different concentrations of 5, 10, 15, 20 and $25 \mathrm{mg} / \mathrm{ml}$, there was a general trend of significant reduction of fungal growth at all employed concentrations of test extract except at the lowest employed concentration of extract at $5 \mathrm{mg} / \mathrm{ml}$, that yielded non significant effect in terms of fungal growth inhibition. At higher concentrations of 10,15, 20 and $25 \mathrm{mg} / \mathrm{ml}$, there was a significant inhibition of 11, 18, 24 and 33\% (Fig. 5B). 


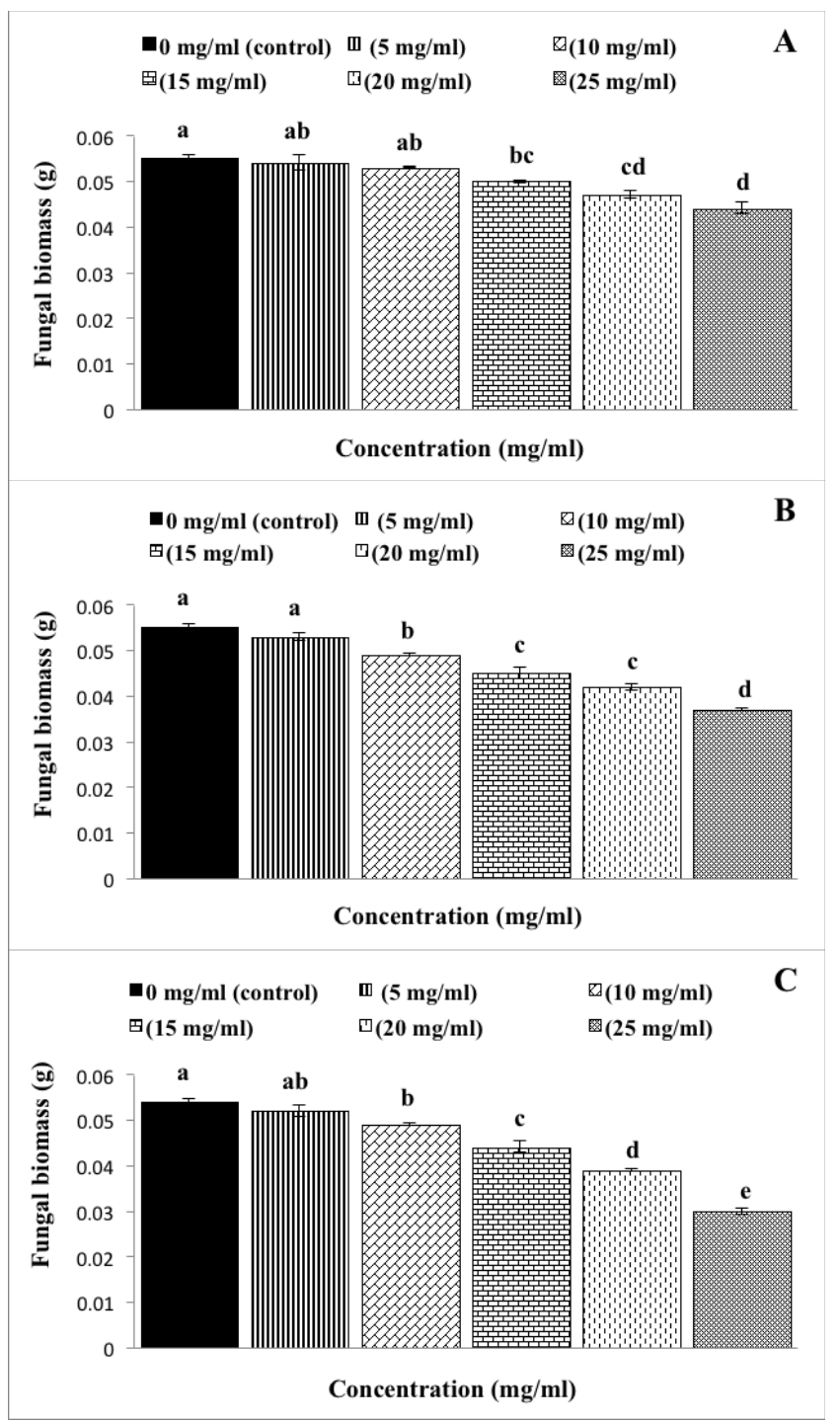

Figure 5. Effect of different concentrations of $(A) n$-hexane, (B) Chloroform and $(C)$ ethyl acetate extract of Agaricus bisporus on biomass of Alternaria alternata. Values topped with distinctive letters show a significant variance $(P \leq 0.05)$, as analyzed by DMRT

Data regarding antifungal activity of ethyl acetate extract against concentrations from $5 \mathrm{mg}$ to $25 \mathrm{mg} / \mathrm{ml}$ are shown in Figure $5 C$. A clear reduction in Alternaria biomass was seen. Ethyl acetate showed better response as compared to $n$-hexane and chloroform extract at $25 \mathrm{mg} / \mathrm{ml}$ concentration and reduced the fungal biomass up to $44 \%$ as compared to control. Bioactivity of ethyl acetate extract against concentrations ranging from $5 \mathrm{mg}$ to $25 \mathrm{mg} / \mathrm{ml}$ was more pronounced as compared to $n$-hexane and chloroform extracts. A clear reduction in Alternaria biomass was seen in both cases. Ethyl acetate showed better response as compared to $n$-hexane and chloroform extract at $25 \mathrm{mg} / \mathrm{ml}$ concentration and reduced the fungal biomass up to $44 \%$ as compared to control (Table 5). The bioactivity recorded in the present investigation was promising as results are better and consistent with the findings of Senka et al. (2011) on A. Alternata where $41.12 \%$ inhibitory activity was reported. Other species of Agaricus, e.g. Agaricus brunnescens are also known to possess antifungal activity. Chloroform, acetone and 
methanol extracts of $A$. brunnescens exhibited antifungal activity against Candida albicans at MIC 39, 19, $39 \mathrm{mg} / \mathrm{mL}$, respectively (Doğan et al., 2013).

Table 5. ANOVA of the data for the effect of n-hexane, chloroform and ethyl acetate extract of Agaricus bisporus on biomass of Alternaria alternata

\begin{tabular}{c|c|c|c|c|c|c|c}
\hline \multirow{2}{*}{ Source } & \multirow{2}{*}{ df } & \multicolumn{2}{|c|}{$\boldsymbol{n}$-hexane } & \multicolumn{2}{c|}{ Chloroform } & \multicolumn{2}{c}{ Ethyl acetate } \\
\cline { 3 - 8 } & & $\mathbf{F}$ & $\mathbf{P}$ & $\mathbf{F}$ & $\mathbf{P}$ & $\mathbf{F}$ & $\mathbf{P}$ \\
\hline $\begin{array}{c}\text { Main effects } \\
\text { Fusarium oxysporum }\end{array}$ & 5 & 11.52 & $.00 * * *$ & 39.48 & $.00 * * *$ & 89.22 & $.00 * * *$ \\
Error & 12 & & & & & & \\
\hline Total & 17 & & & & & & \\
\hline
\end{tabular}

\section{Gas chromatography mass spectrometry analysis (GCMS)}

GCMS analysis demonstrated total 10 compounds were present in the ethyl acetate fraction of A. bisporus mushroom that is shown in Figures 6 and 7. The Retention time (RT), concentration of component (\%) Molecular weight and their molecular formulas are presented in Table 6 .

Table 6. Compounds identified in gas chromatography mass spectrometry analysis

\begin{tabular}{|c|c|c|c|c|c|}
\hline Sr. \# & R. T. (min) & Name of compound & $\begin{array}{c}\text { Molecular } \\
\text { formula }\end{array}$ & $\begin{array}{l}\text { Molecular } \\
\text { weight }\end{array}$ & $\begin{array}{c}\text { Peak area } \\
\%\end{array}$ \\
\hline 1 & 16.239 & Benzene, (1-butylheptyl)- & $\mathrm{C}_{17} \mathrm{H}_{28}$ & 232 & 0.832 \\
\hline 2 & 17.338 & Benzene, (1-butyloctyl)- & $\mathrm{C}_{18} \mathrm{H}_{30}$ & 246 & 0.850 \\
\hline 3 & 17.481 & Benzene, (1-propylnonyl)- & $\mathrm{C}_{18} \mathrm{H}_{30}$ & 246 & 0.554 \\
\hline 4 & 18.323 & Benzene, (1-pentyloctyl)- & $\mathrm{C}_{19} \mathrm{H}_{32}$ & 260 & 0.689 \\
\hline 5 & 18.397 & Benzene, (1-butylnonyl)- & $\mathrm{C}_{19} \mathrm{H}_{32}$ & 260 & 0.595 \\
\hline 6 & 19.348 & $\begin{array}{l}\text { Pentadecanoic acid, 14- } \\
\text { methyl-, methyl ester }\end{array}$ & $\mathrm{C}_{17} \mathrm{H}_{34} \mathrm{O}_{2}$ & 270 & 1.0211 \\
\hline 7 & 19.932 & 1-Hexadecanol, 2-methyl- & $\mathrm{C}_{17} \mathrm{H}_{36} \mathrm{O}$ & 256 & 0.522 \\
\hline 8 & 20.957 & $\begin{array}{l}\text { 9, 12-Octadecadienoic acid } \\
(\mathrm{Z}, \mathrm{Z})-, \text { methyl ester }\end{array}$ & $\mathrm{C}_{19} \mathrm{H}_{34} \mathrm{O}_{2}$ & 294 & 2.864 \\
\hline 9 & 24.799 & $\begin{array}{c}\text { 1,2- Benzenedicarboxylic } \\
\text { acid, mono (2-ethylhexyl) } \\
\text { ester }\end{array}$ & $\mathrm{C}_{16} \mathrm{H}_{22} \mathrm{O}_{4}$ & 278 & 91.310 \\
\hline 10 & 27.874 & $\begin{array}{l}\text { Anthiaergostan-5,7,9,16,22- } \\
\text { penten }\end{array}$ & $\mathrm{C}_{28} \mathrm{H}_{40}$ & 376 & 0.761 \\
\hline
\end{tabular}

R. T. = retention time; $\min =$ minutes

Note: Compound highlighted in boldface was present in the highest concentration

Following compounds were identified in the ethyl acetate fraction of A. bisporus. viz. Benzene, (1-butylheptyl)- (0.832\%), Benzene, (1-butyloctyl)- (0.850\%), Benzene, (1propylnonyl)- (0.554\%), Benzene, (1-pentyloctyl)- (0.689\%), Benzene, (1-butylnonyl)(0.595\%), Pentadecanoic acid, 14-methyl-, methyl ester (1.0211\%), 1-Hexadecanol, 2methyl- (0.522\%), 9, 12-Octadecadienoic acid (Z, Z)-, methyl ester (2.864\%), 1,2Benzenedicarboxylic acid, mono (2-ethylhexyl) ester (91.310\%), Anthiaergostan- 
$5,7,9,16,22$-penten $(0.761 \%)$. Out of these 10 compounds, only one compound (1,2Benzenedicarboxylic acid, mono (2-ethylhexyl) ester) with molecular weight (278) showed $91.31 \%$ peak value. Out of these 10 compounds, only one compound (1,2Benzenedicarboxylic acid, mono (2-ethylhexyl) ester) with molecular weight (278) showed $91.31 \%$ peak value (Figs. 6 and 7). Alshammaa (2017) reported similar compound during their research work. It was concluded that this compound being in highest concentration in the ethyl acetate fraction of $A$. bisporus mushroom is responsible for antifungal activity, recorded in the present study. The present study concludes that $A$. bisporus collected from Pakistan has better antifungal potency that can be exploited as nature friendly alternatives to commercial/synthetic compounds.

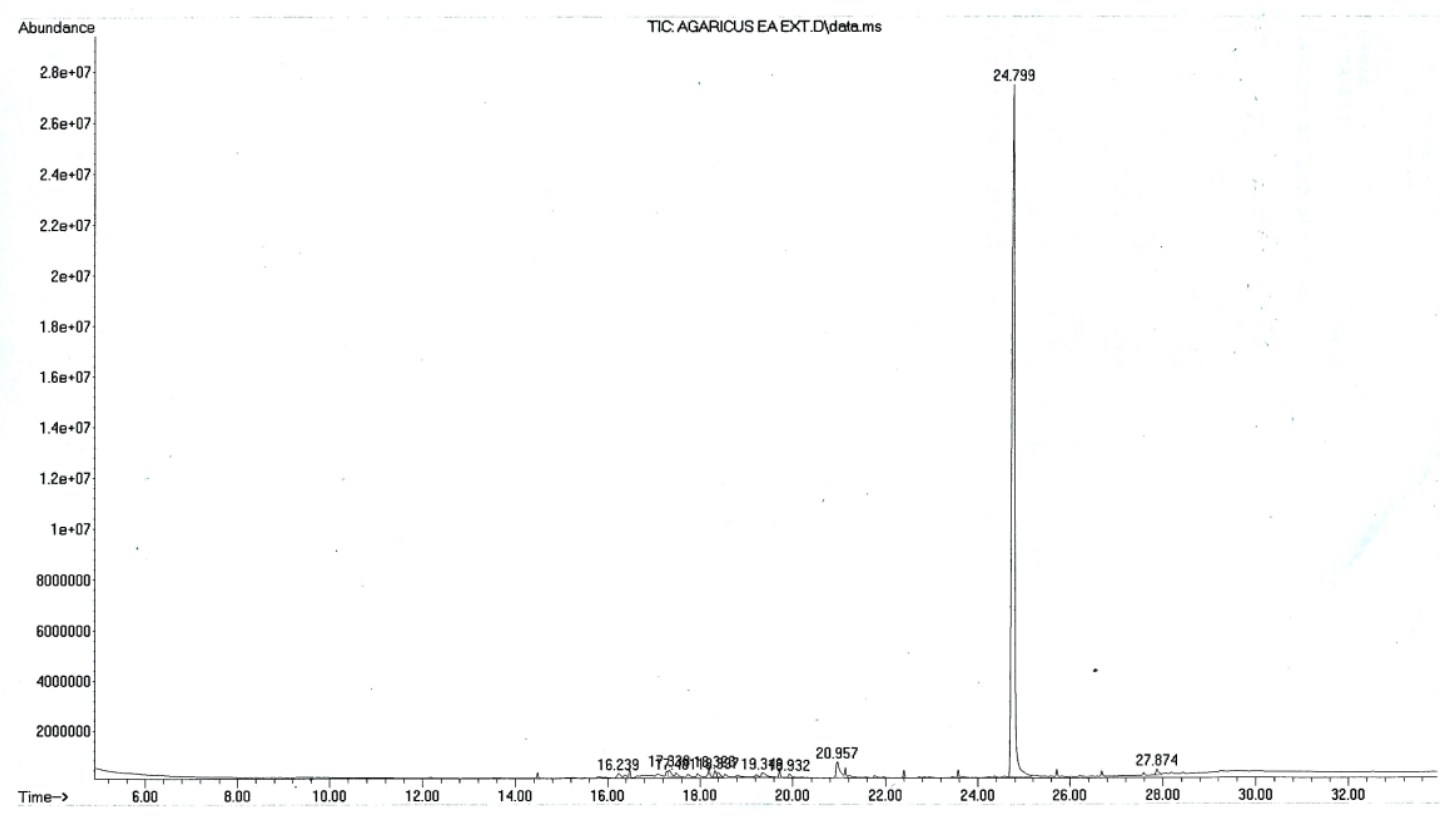

Figure 6. GCMS analysis of ethyl acetate fraction of Agaricus bisporus

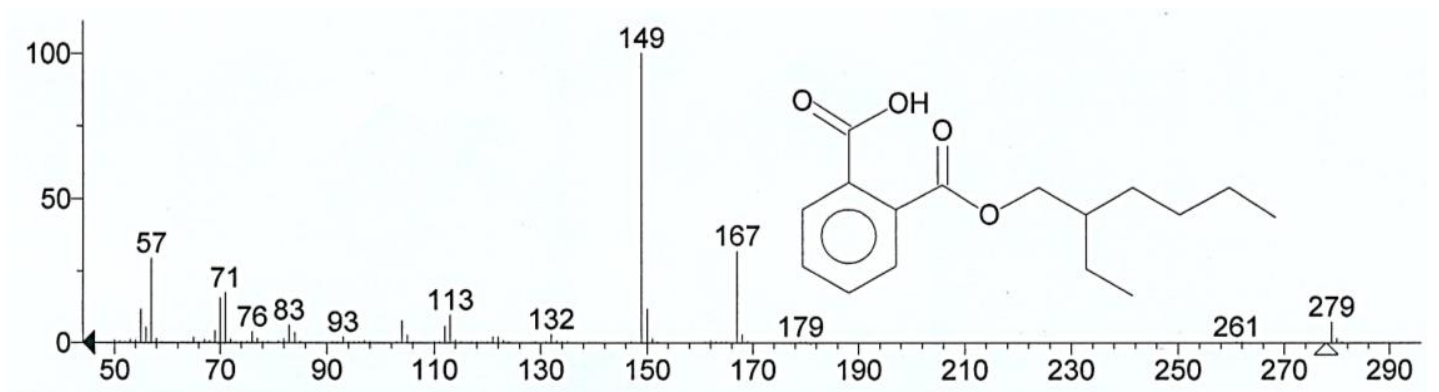

Hit 1. MW: $278 \mathrm{C} 16 \mathrm{H} 22 \mathrm{O} 4$ (mainlib) 1,2-Benzenedicarboxylic acid, mono(2-ethylhexyl) ester

Figure 7. GCMS spectrum and structure of 1,2-Benzenedicarboxylic acid, mono (2-ethylhexyl) ester

\section{Conclusions}

The present study concluded better antifungal activity of ethyl acetate extract of $A$. bisporus collected from Pakistan. GCMS analysis of this fraction revealed the presence of a compound named as 1,2- Benzenedicarboxylic acid, mono (2-ethylhexyl) ester 
having the highest concentration. It may be concluded that this compound was responsible for antifungal activity against a number of phyto-pathogenic fungi. The most susceptible fungal species was $D$. australiensis where ethyl acetate extract caused $50 \%$ reduction in growth. The structure of this compound can be used as structural lead for the synthesis of bioactive antifungal compounds by pesticide/biotechnological companies.

Acknowledgements. Authors are thankful to Dr. Arshad Javaid, Associate Professor, Institute of Agricultural Sciences, University of the Punjab, Lahore, Pakistan, for helping out in the analysis of chemical components through Gas Chromatography Mass Spectrometry (GCMS).

\section{REFERENCES}

[1] Abbas, M. F. Aziz-ud-Din, R., K., Qadir, A., Rashid, A., Qamar, M. I., Rafiq, M., Gleason, M. L. (2017): First report of Alternaria black spot of rose caused by Alternaria alternata in Pakistan. - Plant Disease 101: 391.

[2] Ahmad, I., Hannan, A., Ahmad, S., Asif, M., Nawaz, M. F., Tanvir, M. A., Azhar, M. F. (2017): Fungi associated with decline of kikar (Acacia nilotica) and red river gum (Eucalyptus camaldulensis) in Faisalabad. - International Scholarly and Scientific Research \& Innovation 11: 191-194.

[3] Akbar, M., Iqbal, M. S., Khalil, T. (2017): Isolation and characterization of natural herbicidal compound from Drechslera rostrata. - Planta Daninha 35: 1-6.

[4] Ali, A., Javaid, A., Shoaib, A. (2017): GC-MS analysis and antifungal activity of methanolic root extract of Chenopodium album against Sclerotium rolfsii. - Planta Daninha. DOI: 10.1590/S0100-83582017350100046.

[5] Alshammaa, D. A. S. (2017): Phytochemical investigation and quantitative comparison of ergosterol between Agaricus bisporus and Pleurotus ostreatus by HPLC and GC-MS methods. - International Journal of Pharmaceutical Sciences Review and Research 44: 215-220.

[6] Azhar, N., Khan, M. Q., Riaz, M., Hussain, M. A., Dar, M. E. U. I., Shaheen, H., Bibi, A., Swati, J., Munir, A., Altaf, H., Habib, T. (2018): Measurement of toxic metal contamination, phenolic and flavonoid contents, anticancer, antimicrobial and antioxidant activities of dietary and medicinal plant Juglans regia L. - Applied Ecology and Environmental Research 16(3): 2307-2321. DOI: http://dx.doi.org/10.15666/aeer/1603_23072321.

[7] Dimitrijević, M., Jovanović, V. S., Cvetković, J., Mitić, M., Petrović, G., Đorđević, A., Mitić, V. (2017): Phenolics, antioxidant potentials, and antimicrobial activities of six wild Boletaceae Mushrooms. - Analytical Letters 50: 1691-1709.

[8] Doğan, H. H., Duman, R., Özkalp, B., Aydin, S. (2013): Antimicrobial activities of some mushrooms in Turkey - Pharmaceutical Biology 51: 707-711.

[9] Dutta, S., Monda, T., Some, R. (2013): Studies on antioxidant and antimicrobial properties of some common mushrooms. - Journal of Today's Biological Sciences: Research \& Review (JTBSRR) 2: 60-67.

[10] Gargano, M. L., Van Griensven, L. J. L. D., Isikhuemhen, O. S., Lindequist, U., Venturella, G., Wasser, S. P., Zervakis, G. I. (2017): Medicinal mushrooms: Valuable biological resources of high exploitation potential. - Plant Biosystems 151: 548-565.

[11] Hamid, R. P., Rezaeian, S. (2016): Antimicrobial properties of the button mushroom, Agaricus bisporus. A mini-review. - International Journal of Advanced Research 4: 426429.

[12] Heleno, S. A., Ferreira, I. C. F. R., Esteves, A. P., Ciric, A., Glamoclija, J., Martins, A., Sokovic, M., Queiroz, M. J. R. P. (2013): Antimicrobial and demelanizing activity of 
Ganoderma Lucidum extract, P-Hydroxybenzoic and cinnamic acids and their synthetic acetylated glucuronide methyl esters. - Food and Chemical Toxicology 58: 95-100.

[13] Jananie, R. K., Priya, V., Lakshmi, K. V. (2012): Gas chromatography- mass spectrum analysis of bioactive components of Agaricus bisporus. - Asian Journal of Pharmaceutical and Clinical Research 5: 168-169.

[14] Javaid, A., Qudsia, H., Shoaib, A. (2017): Bioassays guided fractionation of Senna occidentalis for identification of natural antifungal constituents against Macrophomina phaseolina. - Planta Daninha 35: e017163483. http://dx.doi.org/10.1590/s010083582017350100002.

[15] Jin, T. C., Huang, J. W. (2011): Antimicrobial activity of edible mushroom culture filtrates on plant pathogens. - Plant Pathology Bulletin 19: 261-270.

[16] Kothari, D., Patel, S., KiKim, S. (2018): Anticancer and other therapeutic relevance of mushroom polysaccharides: A holistic appraisal. - Biomedicine \& Pharmacotherapy 105: 377-394. https://doi.org/10.1016/j.biopha.2018.05.138.

[17] Kumar, V., Yadav, U. (2014): Screening of antifungal activity of Pleurotus ostreatus and Agaricus bisporus. - Biolife 2: 918-923.

[18] Li, X., Shin, S., Heinen, S., Dill-Macky, R., Berthiller, F., Nersesian, N., Clemente, T., McCormick, S., Muehlbauer, G. (2015): Transgenic wheat expressing a barley udpglucosyltransferase detoxifies deoxynivalenol and provides high levels of resistance to Fusarium graminearum. - Molecular Plant-Microbe Interactions 28(11): 1237-1246.

[19] Maa, G., Yangb, W., Zhaoa, L., Peib, F., Fanga, D., Hua, Q. (2018): A critical review on the health promoting effects of mushrooms nutraceuticals. - Food Science and Human Wellness. DOI: https://doi.org/10.1016/j.fshw.2018.05.002 (in Press).

[20] Masoumi, F., Pourianfar, H. R., Masoumi, A., Mostafavi Mendi, E. (2015): A study of mycelium characterization of several wild genotypes of the button mushroom from Iran.International Journal of Advanced Research 3: 236-246.

[21] Matijaševic, D., Pantic, M., Raškovic, B., Pavlovic, V., Duvnjak, D., Sknepnek, A., Nikšic, M. (2016): The Antibacterial activity of Coriolus versicolor methanol extract and its effect on ultrastructural changes of Staphylococcus aureus and Salmonella Enteritidis. - Frontiers in Microbiology 7: 1226-1301.

[22] Mehmood, N., Riaz, A., Jabeen, N., Anwaar, S., Hussain, S. Z., Abbas, M. F., Zhang, X., Rosli, H., Gleason, M. L. (2017): First report of Fusarium solani causing fruit rot of strawberry in Pakistan. - Plant Disease 101: 1681.

[23] Mehrparvar, M., Goltapeh, E. M., Safaie, N., Ashkani, S., Hedesh, R. (2016): Antifungal activity of essential oils against mycelial growth of Lecanicillium fungicola var. fungicola and Agaricus bisporus. - Industrial Crops and Products 84: 391-398.

[24] Mishra, B. B., Tiwari, V. K. (2011): Natural products: An evolving role in future drug discovery. - European Journal of Medicinal Chemistry 46: 4769-4807.

[25] Naz, F. Abbas, M. F., Rauf, C. A., Tariq, A., Mumtaz, A., Irshad, G., Shaheen, F. A., Hassan, I. (2017): First report of Colletotrichum gloeosporioides causing anthracnose on loquat in Pakistan. - Plant Disease 101: 1550.

[26] Öztürk, M., Duru, M. E., Kivrak, S., Mercan-Doğan, N., Türkoglu, A., Özler, M. A. (2011): In vitro antioxidant, anticholinesterase and antimicrobial activity studies on three Agaricus species with fatty acid compositions and iron contents: A comparative study on the three most edible mushrooms. - Food and Chemical Toxicology 49: 1353-1360.

[27] Ramos, A. M., Gally, M., Szapiro, G., Itzcovich, T., Carabajal, M., Levin, L. (2016): In vitro growth and cell wall degrading enzyme production by Argentinean isolates of Macrophomina phaseolina, the causative agent of charcoal rot in corn. - Revista Argentina de Microbiología 48: 267-273.

[28] Revie, N. M., RIyer, K., Robbins, N., Cowen, L. E. (2018): Antifungal drug resistance: evolution, mechanisms and impact. - Current Opinion in Microbiology 45: 70-76. 
[29] Senka, V., Zoran, Z., Ibrahim, M., Zika, L., Marija, R., Jelena, Z. (2011): The antioxidant properties of polypore mushroom Daedaleopsis confragosa. - Central European Journal of Biology 6: 575-582.

[30] Shu, X., Livingston, D. P., Franks, R. G., Boston, R. S., Woloshuk, C. P., Payne, G. A. (2015): Tissue specific gene expression in maize seeds during colonization by Aspergillus flavus and Fusarium verticillioides. - Molecular Plant Pathology 16(7): 662-674.

[31] Stojkovi, D. S., Grujici, N. K., Reis, F. S., Davidovi, S., Barros, L., Popovi, J., Petrovi, I., Pavi, A., Glamoclija, J., Ciri, A., Stevanovi, M., Ferreira, I. C. F. R., Sokovi, M. (2017): Chemical composition of the mushroom Meripilus giganteus Karst. And bioactive properties of its methanolic extract. - Journal of Food Science and Technology 79: 454462.

[32] Thatoi, H., Singdevsachan, S. K., Patra, J. K. (2018): Prebiotics and Their Production from Unconventional Raw Materials (Mushrooms). - In: Gruemezescu, A., Holban, A. M. (eds.) Therapeutic, Probiotic, and Unconventional Foods (Chapter 5). Academic Press, London, pp. 79-99.

[33] Waithaka, P. N., Gathuru, E. M., Githaiga, B. M., Onkoba, K. M. (2017): Antimicrobial activity of mushroom (Agaricus Bisporus) and fungal (Trametes Gibbosa) extracts from mushrooms and fungi of egerton main campus, Njoro Kenya. - Journal of Biomedical Science 6: 3-10. 